\title{
Lispe (Diptera: Muscidae) of Dominican Republic
}

\section{Lispe (Diptera: Muscidae) Аоминиканской Республики}

\author{
Nikita E. Vikhrev \\ Никита Е. Вихрев
}

\begin{abstract}
Zoological Museum of Moscow University, Bolshaya Nikitskaya 2, Moscow 125009, Russia. E-mail: nikita6510@ya.ru Зоологический музей МГУ им. М.В. Ломоносова, Большая Никитская ул., 2, Москва 125009, Россия.
\end{abstract}

KEY WORDS: Lispe, Muscidae, Diptera, Dominican Republic.

КЛЮЧЕВЫЕ СЛОВА: Lispe, Muscidae, Diptera, Доминиканская Республика.

ABSTRACT. Three species of Lispe were recorded for Dominican Republic, namely L. nasoni Stein, 1898; L. probohemica Speiser, 1914 and L. sordida Aldrich, 1913. Two new synonymies are proposed: L. probohemica $=$ L. argentea Snyder, 1954 syn.n. and L. sordida $=$ L. bahama Snyder, 1958 syn.n. Female of L. probohemica is redescribed. Identification key for Dominican Lispe is proposed.

РЕЗЮМЕ. Три вида Lispe приведены для Доминиканской Республики, а именно: L. nasoni Stein, 1898; L. probohemica Speiser, 1914 and L. sordida Aldrich, 1913. Установлены 2 новых синонима: $L$. probohemica $=L$. argentea Snyder, 1954 syn.n. и $L$. sordida $=$ L. bahama Snyder, 1958 syn.n. Дано переописание самки L. probohemica Snyder, 1954. Дан определительный ключ для доминиканских видов Lispe.

\section{Introduction}

During our two week long collecting trip in Dominican Republic we visited rather dry eastern and southern parts of the island; the wet north-western shore and cool central highlands. We paid special attention to hunting for Lispe on either fresh or salt water bodies, so it is well probably that the Dominican fauna of Lispe is confined to the three species listed in present paper, namely L. nasoni Stein, 1898; L. probohemica Speiser, 1914 and L. sordida Aldrich, 1913. However 2 of 3 discovered species are very curious. The series of $L$. sordida confirms the synonymy of L. bahama Snyder, 1958 previously supposed in [Vikhrev, 2015]. All males of L. probohemica collected in Dominicana have strong vibrissae and, according to Snyder [1954], should be idenfied as L. argentea Snyder, 1954, but in my opinion the length of vibrissae is variable and L. argentea is a synonym of $L$. probohemica. Three of the collected females certainly belong to L. probohemica, that permits me to redescribe female of this species. The redescription is necessary because $L$. argentea was described from the series of males and only the fact that «the middle tarsi are of simple structure» was known
(Aldrich [1913: 137], description of L. spinipes) about the teneral female paratype of $L$. probohemica.

\section{Material and methods}

The specimens listed are in the Zoological Museum of Moscow University (not indicated in text) or Museum für Naturkunde, Humboldt-Universität zu Berlin, Germany (ZMHU). Coordinates are given in the decimal degrees format. The illustrations are original unless otherwise indicated.

The following generally accepted abbreviations for morphological structures are used: $f 1, t 1, f 2, t 2, f 3, t 3=$ fore-, mid-, hind- femur or tibia respectively; $a c$ acrostichal setae; $d c$ - dorsocentral setae; $a, p, d, v=$ anterior, posterior, dorsal, ventral seta(e).

The abbreviation for the tarsi as tar followed by a pair of digits separated by a hyphen was proposed by Vikhrev [2011]: the first digit (1 to 3) gives the leg number and the second digit (1 to 5) the number of the tarsal segment. For example, tar $1-4=4^{\text {th }}$ segment of fore tarsus; $\operatorname{tar} 3-1=$ hind basitarsus.

\section{Lispe nasoni Stein, 1898}

Fig. 8.

Lispe nasoni Stein, 1898. Type locality: USA: South Dakota, Illinois, Georgia.

MATERIAL. Syntypes $20^{7} \sigma^{7}, 2 \circ \circ$ : (USA), Illinois, Algonquin $\left(42.165^{\circ} \mathrm{N} 88.295^{\circ} \mathrm{W}\right)$, W.A. Nason, $15.06 .1895,20^{\top} \sigma^{7}$ and 20.06.1895, 2우 (ZMHU).

Canada, Manitoba, Morris (49.35N 97.36W), 5.08.1953, A. R. Brooks, 1 ㅇ․

Dominicana: Macao env. $18.76^{\circ} \mathrm{N} 68.53^{\circ} \mathrm{W}, 21-22.02 .2016$, N. Vikhrev, $20^{7} 0^{7}$, 6 우우 Constanza env, $18.916^{\circ} \mathrm{N} 70.723^{\circ} \mathrm{W}, 1250$ $\mathrm{m}$ asl, 27-28.02.2016, N. Vikhrev, $8 \mathrm{O}^{7} \mathrm{O}^{7}$, 5우; Barahona env, $18.347^{\circ} \mathrm{N} 71.157^{\circ} \mathrm{W}, 24-25.02 .2016$, N. Vikhrev, 1우 Juan, $19.63^{\circ} \mathrm{N} 70.078^{\circ} \mathrm{W}, 2.03 .2016$, N. Vikhrev, $30^{7} 0^{7}$, 2 웅.

Mexico: Chiapas state, Chiapa de Corzo $\left(16.70^{\circ} \mathrm{N} 93.01^{\circ} \mathrm{W}\right)$, 9.11.2010, A. Grzywacz, $20^{7} 0^{7}$; Sonora state, Ciudad Obregon $\left(27.5^{\circ} \mathrm{N} 109.9^{\circ} \mathrm{W}\right), 16.05 .1961$, Howden \& Martin, $10^{\top}$.

USA: Texas, Davis Mts State Park $\left(30.6^{\circ} \mathrm{N} 103.9^{\circ} \mathrm{W}\right), 19$ 20.07.1973, E. Lindquist, $10^{7}$; Wisconsin, Dane Country $\left(43.1^{\circ} \mathrm{N}\right.$ $89.4^{\circ} \mathrm{W}$ ), 31.07-2.08.1935, F. Snyder, $20^{7} 0^{7}, 1^{\circ}$ (ZMHU).

DISTRIBUTION. Widespread and common species: Canada, USA, Mexico, Bahama and Dominicana. 
Lispe probohemica Speiser, 1914 Figs 1-6.

Lispe probohemica Speiser, 1914. Type locality: USA: California and Idaho.

Lispe spinipes Aldrich, 1913 (nec Bigot, 1885). Type locality: USA: California and Idaho.

Lispe argentea Snyder, 1954. Type locality: (USA), California, Newman, San Joaquin River, syn.n. $\left(37.33^{\circ} \mathrm{N} 120.97^{\circ} \mathrm{W}\right)$. Type series consists of $\sigma^{7}$ holotype and $8 \sigma^{7} \sigma^{7}$ paratypes [Snyder, 1954].

MATERIAL. Dominicana: Macao env. $18.781^{\circ} \mathrm{N} 68.549^{\circ} \mathrm{W}$, 21-22.02.2016, N. Vikhrev, $2 \sigma^{\top} \sigma^{\top}, 300$; Barahona env, $18.289^{\circ} \mathrm{N}$ $71.297^{\circ} \mathrm{W}, 24-25.02 .2016$, N. Vikhrev $4 \sigma^{\top} \sigma^{\top}$.

USA, Georgia, Decatur Co., Spring Creek $\left(30.855^{\circ} \mathrm{N}\right.$ $\left.84.584^{\circ} \mathrm{W}\right), 16-29.07 .1912,10^{\top}$ (ZMHU).

DISTRIBUTION. USA: Arizona, California, Georgia, Idaho, Mississipi, Texas, Washington and Dominicana.

SYNONYMY. Snyder [1954: 10, Fig. 7] gave drawing of the spine-like projection on tar2-4 of L. probohemica as curved and rather pointed (Fig. 3) i.e. different from the straight and blunt shape of this projection in other species of Lispe having this character. Figs 4 and 5 show tar2-4 of the same male specimen from Dominicana, so depending on point of view the projection looks either curved and pointed or straight and blunt. Snyder [1954: 15, Figs 59, 60] proposed differences in the fine structure of the male genitalia of L. probohemica and L. argentea, I believe that these differences are insufficient and unconvincing. Thus, the only dif- ference is that males of $L$. probohemica have the vibrissae indistinct or short, whereas males of $L$. argentea have vibrissae $1.25-1.75 \mathrm{x}$ as long as the greatest width of the palpi. Using Snyder's scale, my Dominican males have vibrissae even longer, about $2.25 \mathrm{x}$ as long as the greatest width of the palpi. Either the series from Dominicana should be described as a new species too or the length of the male vibrissae is variable and (in my opinion) L. probohemica Speiser, $1914=$ L. argentea Snyder, 1954, syn.n.

REDESCRIPTION OF FEMALE (Fig. 1). Head. Frons at level of anterior ocellus 0.37 as wide as head width. Frons black; frontal triangle dirty-yellow; fronto-orbital plates dirtyyellow; face and parafacials white. Fronto-orbital plates with 5 (4) inclinate setae; with 2 reclinate setae in upper part and with outer row of about 12 hairs. Parafacials with 3-6 of hairs in lower part. Antenna black, arista with hairs in basal half. Palpi $1.5 \mathrm{x}$ as wide as width of antenna, yellow. Vibrissae strong.

Thorax densely grey dusted, vittae indistinct. prst $a c$ in 4 rows; $d c 2+3$, all strong. Katepisternals 1+2; anepimeron with 7-10 setulae; meron with 2 setulae above hind coxa. Anterior spiracle not enlarged. Wings hyaline, slightly brownish, calypters white, halter yellow.

Legs black with grey dusting. $t 1$ without submedian seta. $t 2$ with $p d$ and ad setae below middle. Hind coxa without seta on inner posterior surface. $f 3$ with a $4 a v$ and 4-5 longer $p v$ in

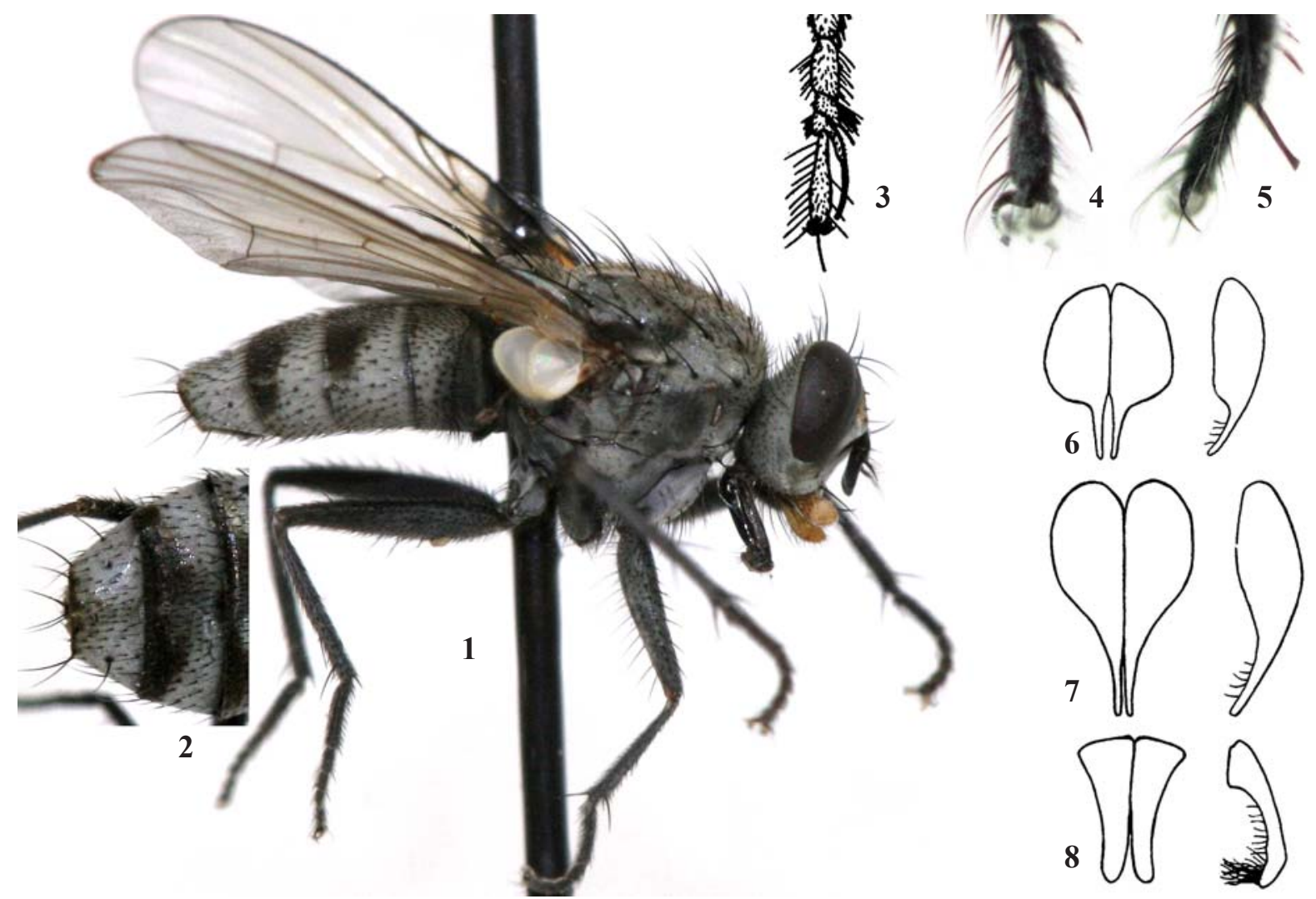

Figs 1-8. Lispe spp.: Lispe probohemica 1-5: $1-q$ general view, lateral; 2 - tip of abdomen, dorsal; $3-\bigcirc^{7}$ mid tarsus by Snyder; $4-\mathrm{O}^{7}$, projection on tar $2-4$ looks curved and pointed; 5 - the same specimen, but under different angle of view projection on tar $2-4$ looks straight and blunt. Cerci of Dominican Lispe by Snyder 6-8: 6 - L. probohemica; 7 - L. sordida; 8 - L. nasoni; 3 - by Snyder [1954: 10, Fig. 7]; 6-8 - by Snyder [1954: 11, Figs 28, 34, 35].

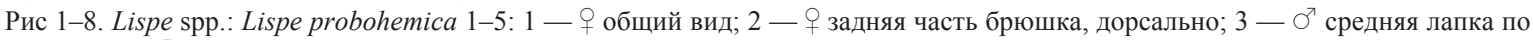
Шнайдеру; 4 - $0^{7}$, шип на tar2-4 выглядит изогнутым и заострённым; 5 - тот же экземпляр, но будучи снят под другим углом, шип выглядит прямым и затупленным. Церки доминиканских видов Lispe по Шнайдеру 6-8: 6 - L. probohemica; 7 - L. sordida; 8 L. nasoni; 3 — по Snyder [1954: 10, Fig. 7]; 6-8 — по Snyder [1954: 11, Figs 28, 34, 35]. 
basal half. t3 with 1 submedian ad. Pulvilli rather long, almost as long as claws.

Abdomen densely grey dusted. Tergites 3 and 4 on posterior half with a pair of large, almost fused triangular black spots; tergites $1+2$ and 5 evenly grey (Figs $1-2$ ).

Diagnosis of female. Identification of females of the L. palposa group are difficult. The important diagnostic characters of female of L. probohemica seem to be: unusual abdominal pattern; yellow and narrow palpi; rather long pulvilly and chaetotaxy of $f 3$.

\section{Lispe sordida Aldrich, 1913}

Fig. 7.

Lispe sordida Aldrich, 1913. Type locality: USA, Utah, Brigham $\left(41.2^{\circ} \mathrm{N} 112.2^{\circ} \mathrm{W}\right)$

Lispe bahama Snyder, 1958. Type locality: Bahamas, S Caicos Isl., $\left(21.5^{\circ} \mathrm{N} 71.5^{\circ} \mathrm{W}\right)$, syn.n.

MATERIAL. Syntypes $L$. sordida, $30^{\top} \sigma^{7}, 4$, Brigham $\left(41.2^{\circ} \mathrm{N} 112.2^{\circ} \mathrm{W}\right)$, (J.M. Aldrich), $4.07 .1911\left(20^{\top} \mathrm{O}^{7}, 3\right.$ 우우, ZMHU and $10^{\prime}, 19$, ZMUM).

Dominicana: Macao env. $18.781^{\circ} \mathrm{N} 68.549^{\circ} \mathrm{W}, 21-22.02 .2016$, N. Vikhrev, 2우; Barahona env, $18.347^{\circ} \mathrm{N} 71.157^{\circ} \mathrm{W}, 24$ 25.02.2016, N. Vikhrev, $80^{\top} \mathrm{O}^{\top}, 3$, ${ }^{\circ}$.

USA, Utah, Roy $\left(41.2^{\circ} \mathrm{N} 112.2^{\circ} \mathrm{W}\right), 25.08 .1957$, G.F. Knowlton, $10^{7}$.

DISTRIBUTION. Widespread in USA, also known from Bahama and Dominicana.

SYNONYMY. L. sordida has several diagnostic characters which make identification of this species easy in both sexes: $t 3$ with 1 short $a v$ in addition to $a d$ seta (unique in the Lispe palposa group); $t 1$ with $1 p v ; t 2$ with $2 p d$ in addition to $1 \mathrm{ad}$; male with mid tarsus modified, tar2-2 shortened, shorter than tar2-3. In the original description Snyder [1958] did not compare L. bahama with L. sordida though such a comparison inevitably comes to mind [Vikhrev, 2015]. So, Lispe sordida Aldrich, 1913 = Lispe bahama Snyder, 1958, syn.n. There are minute differences between Dominican L. sordida and L. sordida from American mainland, the latter has $a v$ setae on $f 3$ longer and parafacials more hairy, so it is possible to regard West Indian population as L. sordida bahama Snyder, 1958, but I prefer to avoid this.
IDENTIFICATION KEY FOR LISPE OF DOMINICAN REPUBLIC $\left(\bigcirc^{\top} \bigcirc^{\top}\right.$, , + )

1. Tibiae yellow. $d c 2+4,2$ anterior pairs of post $d c$ weak. $t 1$ in lower $1 / 3$ with $1 d$ and $1 p v$. $t 3$ with 1 strong and 4-5 shorter $a d$. $\sigma^{7}$ nercal plate as in Fig. 8 ...... nasoni Stein

— Legs entirely dark. $d c 2+3$, all strong. $t 1$ without $d$ with or without $p v$. $t 3$ with only 1 strong $a d$

2

2. $t 1$ with $1 p v$. $t 2$ with $1 a d$ and $2 p d$. $t 3$ with $1 a d$ and 1 short av. Palpi $2 \mathrm{x}$ as wide as width of antenna, dirty-yellowish-brown. $0^{7}$ : $\operatorname{tar} 2-2$ shortened, shorter than $\operatorname{tar2-3}$; tar 2-4 without spine-like projection. Cercal plate long as in Fig. 7 sordida Aldrich

- $t 1$ without submedian seta. $t 2$ with $1 \mathrm{ad}$ and $1 \mathrm{pd}$. $t 3$ with 1 $a d$ and without $a v$. Palpi $1.5 \mathrm{x}$ as wide as width of antenna, yellow. $0^{7}$ : $\operatorname{tar} 2-2$ unmodified, longer than $\operatorname{tar} 2-3$; $\operatorname{tar} 2-4$ at apex with posterior spine-like projection (Figs 3-5). Cercal plate short as in Fig. 6 probohemica Speiser

ACKNOWLEDGEMENTS. I thank Joachim Ziegler and Jenny Polh (Berlin) for important material from ZMHU. I thank Oksana Eremenko (Kharkov, Ukraine) for various support during collecting trip in Dominicana. I thank Oleg Kosterin (Novosibirsk) and Andrey Ozerov (Moscow) for their advices and corrections.

\section{References}

Aldrich J.M. 1913. The North American species of Lispa (Diptera; Anthomyidae) // Journal of The New York Entomological Society. Vol.21. P.126-146.

Snyder F.M. 1954. A Review of Nearctic Lispe Latreille (Diptera, Muscidae) // American Museum Novitates. No.1675. P.1-40.

Snyder F.M. 1958. Muscidae from the Bahama Islands (Diptera) // American Museum Novitates. No.1893. P.1-4.

Vikhrev N. 2011. Review of the Palaearctic members of the Lispe tentaculata species-group (Diptera, Muscidae): revised key, synonymy and notes on ecology // ZooKeys. Vol.84. P.59-70.

Vikhrev N.E. 2015. Taxonomic notes on Lispe (Diptera, Muscidae). Parts 10-12 // Amurian zoological journal. Vol.7. No.3. P.228-247. 